
\title{
Reseserch Suare \\ Soil and Vegetation Patterns Along a Toposequence in a Dolomite Peak-cluster Depression Catchment
}

\section{Qingmei Meng}

Institute of Subtropical Agriculture Chinese Academy of Sciences

\section{Zhiyong Fu ( $\nabla$ zyfu@isa.ac.cn )}

Institute of Subtropical Agriculture Chinese Academy of Sciences https://orcid.org/0000-0002-8996-

1179

\section{Sheng Wang}

Institute of Subtropical Agriculture Chinese Academy of Sciences

Hongsong Chen

Institute of Subtropical Agriculture Chinese Academy of Sciences

\section{Research Article}

Keywords: dolomite, soil catena, nutrient stocks, vegetation patterns, soil-epikarst system

Posted Date: November 8th, 2021

DOI: https://doi.org/10.21203/rs.3.rs-1036345/v1

License: (1) (1) This work is licensed under a Creative Commons Attribution 4.0 International License.

Read Full License 
3 Qingmei Meng ${ }^{\mathrm{a}, \mathrm{b}, \mathrm{d}}$, Zhiyong $\mathrm{Fu}^{\mathrm{a}, \mathrm{d}}$ *, Sheng Wang ${ }^{\mathrm{c}}$, Hongsong Chen ${ }^{\mathrm{a}, \mathrm{d}}$

$4{ }^{a}$ Key Laboratory of Agro-ecological Processes in Subtropical Region, Institute of

5 Subtropical Agriculture, Chinese Academy of Sciences, Changsha, Hunan, 410125,

6 China

$7 \quad{ }^{b}$ Forestry College, Guangxi University, No. 100 Daxue Road, Nanning 530004, China

$8 \quad{ }^{\mathrm{c}}$ Key laboratory of Environment Change and Resources Use in Beibu Gulf, (Nanning

9 Normal University), Ministry of Education, Nanning, Guangxi 530001, China

10 dHuanjiang Observation and Research Station for Karst Ecosystems, Chinese Academy

11 of Sciences, Huanjiang, Guangxi 547100, China

$12{ }^{*}$ Corresponding author: Zhiyong Fu

13 Tel: +86-731- 84619720; Fax: +86-731-84612685; Email: zyfu@isa.ac.cn

14 Postal address: Institute of Subtropical Agriculture, Chinese Academy of Sciences,

15 Changsha, Hunan, 410125, China 
Abstract:

Aim A deeper understanding of relationships between soil and vegetation is a prerequisite for accelerating karst area vegetation restoration. Remarkable achievements have been made at regional and individual plant scales, but research on the relationship between soil and vegetation is insufficient at the hillslope catena scale in karst areas.

Methods Soils and vegetation were investigated along a toposequence (upper-, middle-, lower-slope, and depression) of a dolomite peak-cluster depression catchment. Results A continuous soil catena pattern was developed along the toposequence. From the top to bottom of soil catena, soil thickness, fine soil mass ratio, nutrient stocks, and epikarst thickness gradually increased, while gravel mass ratio, $\mathrm{pH}$, and saturated hydraulic conductivity gradually decreased. However, nutrient contents showed no significant change trends along the soil catena. There was a strong spatial association between soil types and dominant vegetation communities. The associations were as follows: herbs associated with entisols in the upper-slope; herbs and shrubs with inceptisols in the middle-slope; shrubs with semi-alfisols in the lower-slope; and trees with alfisols in the depression.

Conclusions The dolomite rocks displayed an evenly progressive karstification process. This led to an undeveloped underground karstic network incapable of transporting soil materials into underground. Soil materials still accumulated at different topographic positions surface and formed a continuous catena. Parameters for nutrient stock may be more suitable for assessing soil productivity and to guide vegetation restoration key factors in karst regions than nutrient content parameters.

Keywords: dolomite; soil catena; nutrient stocks; vegetation patterns; soil-epikarst 


\section{Introduction}

A toposequence is a spatial object that maintains flow connectivity from summit or hillslope initiation to base, or hillslope conclusion. Catenary soils usually developed along a toposequence because the degree of transport and deposition of particulate constituents in the soil profile differs among soils with different topographic positions (Schlichting 1970; Brunner et al. 2004; Lozano-García and Parras-Alcántara, 2014).

Generally, upper-slope erosion and accompanying lower-slope sedimentation result in gradual soil layer and regolith thickening from the upper-slope to the depression. Regular changes of regolith thickness and soil profile morphological characteristics along a topographic gradient are represent as the primary conceptual model for the soil catenary process (Sommer and Schlichting 1997; Applegarth and Dahms 2001; Lozano-García and Parras-Alcántara 2014). The catena concept indicates soilvegetation combination spatial patterns located on a specific landform. However, soil and vegetation characteristics can vary significantly along a toposequence among at different environment factors such as parent materials, climate, topography and human activities (Boling et al. 2008; Podwojewski et al. 2011).

Karst peak-cluster depression is a special geomorphic unit surrounded by slopes which, within a very short horizontal distance, shows rapid changes, from, for example, a close-to- $90^{\circ}$-cliff to a relatively flat depression. Potential energy decreases sharply from the slope top to the depression leading to a remarkable potential gradient between the slope part and the depression part. Spatially, soils and vegetations in this unique peak-cluster depression system have the topographic and hydrological conditions to 
form a catenary pattern. However, for the karst landscape, knowledge about the soilvegetation relationships were mostly relied on the results carried out in regional or plant individual scales. Related studies in catchment or catenary scales are relative rare due to the ubiquitous extremely high structural heterogeneity in these scales. For instance, in karst regional scale, Jiang et al. (2014) found that bedrock geochemistry via influencing the regolith water-retention capacities determined the karstic vegetation productivity. In individual plant scale, karstic site-specific characteristics such as bedrock outcrops extent and soil thickness were the main controlling environment factors and determining plant community composition (Liu et al. 2019). Thin soils were dominated by shallow-rooted plants preferring surface soil water, while continuous carbonate rock outcrops were usually dominated by deep-rooted plants preferring rock crevices water (Nie et al. 2010, Ding et al. 2020). Considering that hillslopes and catchments are often as basic management units for implementing ecological restoration in severely degraded karst ecosystems (Jiang et al. 2014), there is a strong need to conduct works to bridge the perception gap in the catenary scale.

Moreover, with regard to the soil forming characteristics of karst slope land, through extensive implementation of pedon scale excavation at the complete landform scale of peak-cluster depressions, systematic studies on soil formation processes and soil catena patterns are also still insufficient. Scholars generally believe that the high $\mathrm{Ca}$ and $\mathrm{Mg}$ content of carbonate rocks and unique karstification processes hinder the loss of saltbased components in soil and desilicification and allitization. Researchers usually regard calcareous soil as a soil category in entisols. There are four sub-categories of calcareous soils: black; brown; yellow; and, red calcareous soil. Typically they are shallow, not obviously stratified, clayey, and abruptly contact the underlying rock. 
These results are based on the PRC's second national soil survey, which was aimed at cultivated soils on gentle slopes. Soil resources of mountainous areas were not comprehensively studied. Fully grasping the soil-vegetation relationship and the key controlling factors in the catenary scale are the basic prerequisites for the rational use of scarce soil resources in karst catchments.

Soil parent material, special hillslope hydrological processes, and topography, affects catena formation in many ways in karst areas. Three factors are in play: 1) The Southwestern China karst area is low in acid-insoluble and insufficient sources of soilforming materials in carbonate rocks. When soil-forming materials are extremely scarce, whether it can form a soil catena with obvious soil development sequence? 2) Carbonate bedrock forming slopes are characterized by highly induced porosity resulting in a well-developed underground drainage system. These often outcrop at or near the surface. They facilitate rapidly surface water transport underground, even during rainfall and runoff events (Williams 1983; Feng et al. 2016). Hillslope scale overland flow rarely occurs in karst areas compared to non-karstic areas (primarily silicate rocks). How does this affect the hydrodynamic conditions that drive the downward and lateral migration of soil materials at different topographic positions? Will it affect the differential sorting and redistribution of soil particles across the slope? 3) In karst catchment, slopes and depressions, what the characteristics of rapid changes in short distances, and the transition between the two are not obvious. This is clearly different from non-karst area topographic position characteristics, where slope gradually descends and transitions to valley floor, thus forming a long slope. Whether karst slope land is able to form a soil catenary pattern similar to non-karst areas, it remains to be determined by field investigations. 
112

113

was to verify the hypotheses that: (1) dolomite slope can still present a typical soil catena pattern; (2) vegetation communities and soil types are spatially associated in this dolomitic peak-cluster depression catchment.

\section{Materials and Methods}

\subsection{Study area}

This study was conducted in a typical karst catchment located at $24^{\circ} 43^{\prime} 58.9^{\prime \prime} \sim 24^{\circ} 44^{\prime} 48.8^{\prime \prime} \mathrm{N}, 108^{\circ} 18^{\prime} 56.9^{\prime \prime} \sim 108^{\circ} 19^{\prime} 58.4^{\prime \prime} \mathrm{E}$ in Mulian, Huanjiang County, Guangxi (Fig. 1). The area is $1.46 \mathrm{~km}^{2}$ and an elevation of 272 to $647 \mathrm{~m}$ above sea level. It is in a subtropical mountain monsoon climate zone which has an average annual rainfall of $1389 \mathrm{~mm}$. The rainy period is May-October and accounts for $70 \%$ of the annual rainfall (Hu et al. 2015). Annual average temperature in this area is between 19.6-21. $6^{\circ} \mathrm{C}$. The lowest temperatures, about $3.4 \sim 8.7^{\circ} \mathrm{C}$ occurs in January -March. The highest, $23.0-26.7^{\circ} \mathrm{C}$, in July-September. Slope soil is shallow. Gravel content is high. The soil thickens gradually from slope to depression. Since 1985, the government has carried out a "returning farmland-to-forest" policy. The area is recovering to a natural state. The main trees are Radermachera sinica, Celtis biondii, Rhus chinensis, Schefflera heptaphylla. The shrubs are Vitex negundo and Ligustrum lucidum, Pyracantha fortuneana. The precominant herbs are mainly Miscanthus floridulus, Bidens pilosa and Pteridium aquilinum.

Mulian catchment is in the western wing of the Mulian anticline. Its aquifer is primarily constituted of middle and late Carboniferous dolomite with a strata orientation of $278^{\circ} \angle 10^{\circ}$. It is underlain by an early Carboniferous sandstone aquifer which is relatively impermeable (Fig. 1). The underlying rocks are very pure dolomite 
rocks. Borehole analysis suggests that karstification degree decreases as depth increases.

136

137

Study area karstification is characterized by penetrating dissolution pores, micro-tensile dissolution fractures, and local dissolution fractures. Its highly weathered dolomite is mostly lost its original rock structure and even deconstructed into dolomite sand. There is no obvious bubble reaction obtained after dropping dilute hydrochloric acid on it.

\subsection{Methods}

\subsubsection{Soil, rock, and vegetation characteristics}

The four topographical positions along the toposequence in Mulian catchment: upper-, middle- and lower-slopes, and depression were examined for soil, rock, and vegetation characteristics (Fig. 1). At each topographical position, a $400 \mathrm{~m}^{2}(20 \mathrm{~m} \times 20$ m) vegetation survey plot was established. The $400 \mathrm{~m}^{2}$ large sample plot was divided into plots: $10 \mathrm{~m} \times 10 \mathrm{~m}$ for a tree survey; $5 \mathrm{~m} \times 5 \mathrm{~m}$ for a shrub survey; and $1 \mathrm{~m} \times 1 \mathrm{~m}$ for an herb layer survey. Species name, height, diameter at breast height and plant number of trees, shrubs and herbs in the investigated plots were recorded.

Due to the strong spatial heterogeneity in the karst area, a total of 14 soil pits were used: three for both upper-slope and depression positions, and 4 for both mid-slope and lower-slope positions (Table S1), for soil profiles description and soil samples collection. Soil pits were excavated to the $\mathrm{C}$ horizon or the epikarst zone. The main topographic variables, including altitude, slope gradient and gravel content, and soil profile morphological characteristics for each soil pits were recorded and described according to FAO-ISRIC-ISSS (2006) (Wrb 2006). Triplicate bulk soil samples, of about $5 \mathrm{~kg}$, were taken for each soil genetic horizons from all side of the pits. Traditional small metal cylinder with a volume of $100 \mathrm{~cm}^{3}$ were unsuitable for solid cores from rocky soils of this karst catchment. Large PVC tubes with height $15 \mathrm{~cm}$, inner diameter 
of $10 \mathrm{~cm}$, and a volume $1178 \mathrm{~cm}^{3}$ were fabricated and used as soil cylinders to obtain undisturbed soil samples.

A series of boreholes (with a diameter of $15 \mathrm{~cm}$ ) were made in the upper-, middle-, lower-slopes and depressions in order to study near-surface hydrological processes in the slope-depression system. Borehole core profiles were photographed and described during the drilling process of the sampling of dolomite rocks from the middle-slope and the depression which were collected to analyze chemical composition.

\subsubsection{Determination of soil physical properties}

Soil saturated hydraulic conductivity was determination: first by putting the soil cylinder samples into a sink. The sink liquid level of the sink was $2 \mathrm{~cm}$ below the upper end of the soil cylinder. Soaking for 12 hours was allowed for the soil to fully absorb water and saturated. Then constant-head method was used to measure soil saturation hydraulic conductivity.

$$
K_{S}=\frac{10 Q L}{A \Delta H T}
$$

In this formula, $K_{S}(\mathrm{~mm} / \mathrm{min})$ is saturated hydraulic conductivity. Q-outflow $(\mathrm{ml})$ is within $\mathrm{t}$ time. $\mathrm{L}(\mathrm{cm})$ is linear distance of the water flow path. $\mathrm{A}\left(\mathrm{cm}^{2}\right)$ is the water flow cross-sectional area. $\Delta \mathrm{H}(\mathrm{cm})$ is the total head difference between the beginning and end of the seepage path. T ( $\mathrm{min}$ ) is the outflow time (Yi et al. 2019).

Determination of the soil material composition included gravel and fine soil component: Soil cylinder was the total volume of soil material $\left(V_{T}-\mathrm{cm}^{3}\right)$. Soil cylinder contents were transferred to an oven baked at $105^{\circ} \mathrm{C}$, and dried for 12 hours. And then weigh to obtain total soil cylinder mass. This was the total soil material mass $\left(M_{T}-\mathrm{g}\right)$. Gravels, defined as having a diameter $>2 \mathrm{~mm}$ were selected and provided the gravel component total mass $\left(m_{g}-\mathrm{g}\right)$. What remained was the fine soil component which were 
184

185

sieved through a $2 \mathrm{~mm}$ sieve. Dried cylinders sample gravel was water-soaked for 12 hours fully saturation. Using drainage method determined gravel volume $\left(v_{g}-\mathrm{cm}^{3}\right)$ (Wang et al. 2017). Gravel density $\left(\rho_{g}\right.$-g/ $\left./ \mathrm{cm}^{3}\right)$ could be calculated as:

$$
\rho_{g}=m_{g} / v_{g}
$$

The values determined above were used to calculate fine soil mass ratio $\left(M_{F^{-}} \%\right)$, gravel mass ratio $\left(M_{G}-\%\right)$, fine soil volume ratio $\left(V_{F}-\%\right)$, and gravel volume ratio $\left(V_{G^{-}} \%\right) . v_{f}$ is fine soil volume $\left(\mathrm{cm}^{3}\right)$, the formula was as follows:

$$
v_{f}=V_{T}-v_{g}
$$

$$
V_{F}=v_{f} / V_{T} \times 100 \%
$$$$
V_{G}=v_{g} / V_{T} \times 100 \%
$$

Fine soil texture was determined using the hydrometer method.

Soil bulk density (BD), and fine soil bulk density $(\delta f)$ indicated as the bulk density of the total soil material and of the soil material excluding gravel component, respectively. They were calculated as follows.

$$
\begin{aligned}
B D={ }^{M} / V_{T} & \\
& \delta_{f}=\left(M_{T}-m_{g}\right) /\left(V_{T}-v_{g}\right)
\end{aligned}
$$

$M_{T}(\mathrm{~g})$ is total soil mass. $V_{T}\left(\mathrm{~cm}^{3}\right)$ is total soil volume. $m_{g}(\mathrm{~g})$ is gravel mass. $v_{g}\left(\mathrm{~cm}^{3}\right)$ is gravel volume.

\subsubsection{Calculating of pedon scale average nutrient content and nutrient stocks}

There was a significant positive correlation between soil thickness and vegetation productivity. This correlation became more significant for the soil thickness in the $0-50$ cm (Li and Duan 2014). Shallow soil nutrient stocks affect productivity which is not 
only solely controlled by the soil nutrient content. Karst slope soil was generally

209

210

shallow. Lower-slope and depression soils were relatively deep. Soil nutrient content may not fully reflect actual soil productivity. This study compared average nutrient content with nutrient stocks within the pedon scale to explore the appropriate index for assessing shallow and high gravel soil productivity in peak-cluster depressions.

The soil nutrient content $\left(N_{c}\right)$ parameters include total nitrogen $(\mathrm{TN})$, total phosphorus (TP), total potassium (TK) content, and soil organic matter content parameters which were measured and calculated according using the techniques used by Bao (2000).

This study used the calculation method of soil organic carbon stocks presented in the second edition of the "2011 Soil Investigation Laboratory Information Handbook" of the Natural Resources Conservation Service of the United States Department of Agriculture for soil nutrient stocks index (U.S. Department of Agriculture; Fei et al. 2015).

The PVC tubes, with a volume of $1178 \mathrm{~cm}^{3}$, described above to collect soil cylinders were used. These soil cylinders did not all have the same height. The true soil cylinder height was the sum of the fine soil height and gravel height. The gravel height of each soil layer, represented by $d_{g}(\mathrm{~cm})$, fine soil height of each soil layer, represented by $d_{f}(\mathrm{~cm}) . d_{g}$ and $d_{f}$ could be calculated using the actual soil layer thickness, D $(\mathrm{cm})$, for each soil layer. According to the area of PVC tube bottom was equal, so the ratio of gravel volume $\left(v_{g}-\mathrm{cm}^{3}\right)$ to fine soil volume $\left(v_{f}-\mathrm{cm}^{3}\right)$ was consistent with the ratio of gravel height to fine soil height of soil cylinders. The ratio of $d_{g}$ and $d_{f}$ is approximately equal the ratio of gravel height to fine soil height for a soil cylinder. Therefore, it was equal to the ratio of gravel volume to fine soil volume. This is the 


$$
v_{g} / v_{f}=d_{g} / d_{f}
$$

$$
\mathrm{d}_{\mathrm{g}}+\mathrm{d}_{\mathrm{f}}=D
$$

According to the gravel height and fine soil height for each soil layer, calculate the

gravel volume $\left(V_{1}-\mathrm{cm}^{3} / \mathrm{m}^{2}\right)$ and the fine soil volume $\left(V_{2}-\mathrm{cm}^{3} / \mathrm{m}^{2}\right)$ of the soil layer per unit area. Gravel density $\left(\rho_{g}-\mathrm{g} / \mathrm{cm}^{3}\right)$ were used to calculate the mass of gravel per unit area of soil $\left(m_{1}-\mathrm{kg} / \mathrm{m}^{2}\right)$. Fine soil bulk density $\left(\delta_{f}-\mathrm{g} / \mathrm{cm}^{3}\right)$ were used to calculate the mass of fine soil per unit area of soil $\left(m_{2}-\mathrm{kg} / \mathrm{m}^{2}\right) . m_{t}$ represents the total mass of soil per unit area. This the formula:

$$
\begin{aligned}
V_{1}= & d_{g} \times 10^{4} \\
V_{2}= & d_{f} \times 10^{4} \\
& m_{1}=V_{1} \times \rho_{g} \times 1000 \\
& m_{2}=V_{2} \times \delta_{f} \times 1000 \\
m_{t}= & m_{1}+m_{2}
\end{aligned}
$$

In the calculation of the nutrient stocks per unit area of each soil layer, $N_{S}$ is the nutrient stocks per unit area for each soil layer measured as $\mathrm{kg} / \mathrm{m}^{2} . N_{c}$ is the each soil layer nutrient content measured as $\mathrm{g} / \mathrm{kg}$. The formula was as follows:

$$
N_{s}=m_{2} \times N_{c} \times 1000
$$

Pedon scale nutrient stocks is equal to the sum of gravel nutrient stocks and fine soil nutrient stocks for each soil layer, but the gravel nutrient content is extremely low (Table S2), resulting in the low nutrient stocks of gravel, and negligible. Therefore, the nutrient stocks of the pedon scale are equal to the sum of the nutrient stocks of fine soil in each soil layer. Specific values of nutrient content and nutrient stocks for each soil genetic horizons are in Table S3.

\subsection{Data analysis}

Excel 2019 was used to process data. One-way analysis of variance and Duncan 
method analyzed soil physical and chemical properties differences. The significance

259

260

261

262

263

264

265

266

267

268

269

270

271

272

273

274

level was set at $a=0.05$. Pearson correlation analysis tested correlation between topographic factors, soil properties, and vegetation factors. Origin 2021 drew related charts.

\section{Results}

\subsection{Spatial variability of soil formation characteristics along the toposequence}

\subsubsection{Soil formation conditions at different topographic positions}

Peak-cluster depressions have a unique landform resulting from the long-term karstification process. The hillside abruptly changes into a depression. The height difference from the peak-cluster top to the depression was about $377 \mathrm{~m}$. The slope was about $400 \mathrm{~m}$ long. The depression was about $300 \mathrm{~m}$ wide. The slope length-to depression width was about 4:3. Slopes and depressions areas respectively accounted for $64 \%$ and $27 \%$ of the catchment area. The peak-cluster depression subdivides into four topographic positions. 1) exposed bedrock cliffs with a slope close to $90^{\circ} .2$ ) an mostly exposed rock upper-slope with a slope of $32^{\circ}$; a greater exposed rock mid-slope with of $23^{\circ}$; and, less exposed rock lower-slope of $18^{\circ}$.

Soil-forming material spatial distributions at different topographic positions show a sorting phenomenon from coarse to fine. Between the cliff and the depression, the large weakly-weathered rock mass changes to a moderately-weathered rock mass, then to strongly-weathered clastic rock ending in dolomitic sand layer (Table 1).

The drilling cores's average mass contents for $\mathrm{CaO}$ and $\mathrm{MgO}$ were about $31 \%$ and $21 \%$, respectively (Table 1). Average mass content of acid-insoluble account for about $0.17 \%$ of total rock mass. This suggests a very pure dolomite rocks in this study 
catchment. As the slope decreases, the soil $\mathrm{pH}$ value of the soil gradually decreased

282

283

(Table 1). Upper-slope and mid-slope soil $\mathrm{pH}$ inherited the high alkaline characteristics of the underlying weathered dolomite. Lower-slope soil $\mathrm{pH}$, particularly in depressions, reduced to neutral, or acidic. That soil's properties were less affected by the underlying bedrock.

\subsubsection{Soil profile morphological characteristics in different topographic positions}

Soil profile for different topographic positions can be divided into three soil genetic horizons having dissimilar properties. They are a designated A; AC or B; and C. The "A" layer is black surface layer. "AC or B" is a yellow illuvial horizon and "C" is a white dolomite strongly weathered layer (Table 1). There is a deep dolomite weathering layer in the study catchment. The degree of weathering decreases with depth (Table 1). The differences in the degree of dolomite weathering at different topographic positions are that weathering weakest on the upper-slope where the weathered layer was $1.5 \mathrm{~m}$. The thickness of the dolomite strongly weathered layer in other topographic positions from $2.5 \mathrm{~m}$ to $10 \mathrm{~m}$. The dolomite weathered layer was dominated by fine sand formed by overall dissolution. There were no large pores, cracks, karst conduits and other structures in the weathered layer. The boundary between soil and dolomite weathering layer was clear to the naked eye. The contact surface between the two showed an extremely irregular wavy shape. No soil particles had migrated vertically through the rock weathering layer. From the upper-slope to the depression, soil profiles property changes were obvious. Soil thickness increased gradually (Table 1). The A-C transition layer become more visible. Gravel content decreased gradually. Soil fine particle proportions gradually increased. Lower-slope and depression soil presented B layer which was an obvious illuvial horizon. 
306

307 entisolic and weakly developed. Differentiation between the various soil layers was not obvious. Upper-slope soil was shallow and black with a high gravel content. Middle slope soil was cambisolic, and soil profile development degrees were low. A light yellow weak illuvial horizon was observed under the black surface layer suggesting a weak eluvial and illuvial process. Lower-slope soils were semi-luvisolic having good drainage. The soil profile was moderately developed and a yellow-brown sedimentary layer was easily detected. Depression soil with a yellow surface was highly developed and alfisolic. It had an apparent illuvial horizon. The lower part of it is affected by lateral seepage and formed calcareous concretions and iron-manganese nodules.

\subsection{Soil physico-chemical characteristics along the toposequence}

\subsubsection{Soil physical properties at different topographic positions}

Upper- and middle-slope soil profiles were composed mainly of gravel. Upper slope average gravel mass and volume ratios were $73 \%$ and $64 \%$ respectively (Fig. 2 ). In the middle slope these were $78 \%$ and $47 \%$ respectively. Lower-slope and depression soil profiles were mainly fine soil. Lower-slope gravel mass and volume ratios were $1.30 \%$ and $1.09 \%$, respectively. Depression ratios were $0.21 \%$ and $0.24 \%$. Gravel mass and gravel volume proportions decreased as slope decreased. Fine soil mass and fine soil proportion volumes showed the opposite trend which are obvious slope colluvium characteristics (Fig. 2).

There was a high average clay content of between $32 \%-52 \%$ in lower-slope and depression profiles (Fig. 3). Lower-slope clay content relatively smoothly, with depth (Table 2). Upper and middle slopes have higher sand content which increases with depth. 
329

330

lower-slope and depression belong to the clay group. Saturated hydraulic conductivity decreased as the soil depth increase (Table 2). Depression saturated hydraulic conductivity was the least with a maximum value only $61 \mathrm{~mm} / \mathrm{h}$ (Table 1). Middle slope maximum saturated hydraulic reached $5095 \mathrm{~mm} / \mathrm{h}$. Dolomite slope land is entisolic with high permeability and well drainage. Depression land soil is alfisolic with low permeability and poorly drained.

\subsubsection{Average nutrient content and nutrient stocks at different topographic positions}

If there is a "rule of nutrient content change" along a slope it was not obvious (Fig. 4). Soil nutrient stocks gradually increase at different topographic positions. This largely agrees with soil thickness and apparent soil productivity trend changes along the slope. Soil TN $\left(2.07 \mathrm{~kg} / \mathrm{m}^{2}\right)$, TP $\left(1.19 \mathrm{~kg} / \mathrm{m}^{2}\right)$, TK $\left(9.68 \mathrm{~kg} / \mathrm{m}^{2}\right)$, and organic matter $\left(47.68 \mathrm{~kg} / \mathrm{m}^{2}\right)$ nutrient stocks were all significantly higher than for the upper- and middle-slopes (Fig. 4). Soils of karst areas are commonly shallow and gravelly, thus pedon scale nutrient stocks may be a more suitable measure than nutrient content to assess soil productivity.

\subsubsection{Nutrient accumulation in A-layer}

This study determined that soil nutrient surface accumulation was significant. A layer nutrient, alone, are not an accurate measure of reflect soil fertility and productivity. Upper-slope A layer have the greatest accumulation. It ranges from 63\%-85\% (Fig. 5). Middle-slope accumulation ranges from 60\%-76\%. Lower-slope accumulation was between $33 \%-56 \%$ and for depressions it was $22 \%-26 \%$ (Fig. 5). A layer of depression accumulated relatively few nutrients. Along a slope, nutrient accumulate of A layer gradually lessens. From the characteristics of the black soil layer (Table 1) of upper- 
353

354

355

356

357

358

359

360

361

362

363

364

365

366

367

368

369

370

371

372

373

374

accumulation was significantly stronger than that of the depression.

Upper-slope surface layer fine soil volume was the greatest at 53.64\% (Fig. 6).

Middle-, lower-, and depression values were 40.96\%, 45.10\%, and 33.29\% respectively.

Surface accumulation increased as the amount of fine soil increased except for lowerslopes.

\subsection{Vegetation patterns responses to topographic change}

\subsubsection{Vegetation changes along the toposequence}

On the upper-slope, herbs were about $45 \%$ of all plants and shrubs about $36 \%$ (Table 4). On the mid-slope, shrubs were $58 \%$ and herbs $26 \%$. On lower-slopes shrubs and herbs were $62 \%$ and $23 \%$. In depressions, herbs were $55 \%$ and trees were $42 \%$. Number of trees increased as slope decreased. Initially the shrub increased as position decreased and but then decreased. Plant population was greatest on lower-slopes mainly consisting of shrubs and herbs. Middle-slopes had the least number of plants. Shrubs and herbs predominated on upper- and middle-slopes. Depressions were mainly trees and herbs. Vegetation patterns changed from shrubs to trees with the top to bottom of slope.

\subsubsection{Correlation among topographic, soil properties, and vegetation factors}

All measured factors were divided into three categories: 1) topographic factors which includes slope position, soil thickness, gravel coverage, and slope; 2) soil properties which includes, among other measures, soil bulk density, fine soil bulk density, saturated hydraulic and conductivity; 3) vegetation factors which includes tree, shrubs and herbs type and number. Topographical factors Sp and Sd significantly negatively 
Sd significantly positively correlated with Clay, $\mathrm{M}_{\mathrm{F}}, \mathrm{m}_{2}$, pedon scale nutrient stocks.

377 This suggests that topographic factors have an influence on the variation of soil properties. Sand, pedon scale nutrient stocks, and $\mathrm{M}_{\mathrm{G}}$, significantly correlated with

379 vegetation factors, indicating that soil properties closely relate to vegetation factors.

380 The four parameters in the topographic factors all significantly correlate with the 381 vegetation factors.

382

\section{Discussion}

\subsection{Dolomite-slope shallow soil forms a continuous soil catena pattern}

In non-karst areas, the weathering of rock is dominated by physical weathering, supplemented by chemical weathering. Weathering usually occurs at, or close to, the surface. Weathering affected deep bedrock physical and chemical characteristics less (Worthington et al. 2016; Beven et al. 2021). Carbonate rock is generally solvable, therefore karst-area chemical rock weathering processes are often stronger than physical weathering processes (Gilfillan et al. 2009, Ford and Williams, 2015). The weakly acidic water continuously dissolves the deep carbonate bedrock. In limestone networks are formed. In dolomite the process is diffuse. This results in greater weathered rock layer depth in karst areas which may vary from 10-1000 m (Hartmann et al. 2017). It also results in more and more robust spatial heterogeneity of the material structure. The drilling core profiles showed that dolomite weathered layer thicknesses could beyond $50 \mathrm{~m}$. Strongly-weathered and the weakly weathered layers alternated. This result provided field solid evident to confirm that, in a karst area, the chemical dissolution in carbonate weathering process is dominated. 
399

400

401

402

403

404

405

406

407

408

409

the hillslopes are relatively low, thus bare rocks are no barriers to the continuous soil distribution. Even where soil was shallow and the dolomite strongly weathered and the weathering layer was thick, the dolomitic weathering was characterized by diffuse and integral dissolution. As a result, karst fissures and conduits were not well developed.

Soil was mainly distributed on the surface. Vertical, water-driven migration into underground karst voids was not detected. This suggests that even in stronglyweathered dolomite eluvium pore structures predominate. Water, but not soil particles, channels through small pores. This results in dolomite soil slopes having a soil catena pattern similar to non-karst areas where soil gradually thickens and continuous distributes along a slope.

Compared with soil catena developed in non-karst areas, those developed on dolomite slopes have a short average distance between adjacent soil types, while the number of soil types differs less to non-karst areas. Brunner et al. (2004) studied a Ugandan soil catena, which consisted of granites, gneisses and schists of the Precambrian age. The soil catena there was composed of seven primary soil types. The average distance between adjacent soils was $300 \mathrm{~m}$. Deressa et al. (2018) studied a soil catena, which consisted of alluvium, granitic gneiss and basalt. That soil catena had five soil types. The average distance between adjacent soil types was $10 \mathrm{~km}$. Tsai et al. (2010) studied a Taiwan soil catena composed of two-pyroxene andesites and twopyroxene hornblende andesites. That soil catena had three soil types. The average distance between adjacent soil types was $1833 \mathrm{~m}$. In the instant study, the dolomite soil catena consisted of four soil types. The average distance between adjacent soil types was $33 \mathrm{~m}$. 
423

424

425 recharges groundwater. The surface runoff coefficient was far less than non-karst mountain slopes. The stronger karst slope vertical water flow drives soil profiles soil formation processes more quickly than for non-karst slopes. It seems likely that the more rapid vertical water flow present in a dolomite soil profiles replaces the lack of a hydrological driving force resulting from short slopes and a steep topography. A dolomite slope can also present a complete soil catena pattern.

The dissolution rate of limestone was 2 to 60 times higher than dolomite (Bai and Wang 2011). Limestone is characterized by highly differentiated dissolution. The fissures and large conduits network structure in the limestone weathered layer were extremely developed. These structures often become preferential channels for material migration underground (Fig. S1). In the limestone zone, the well-developed underground network void structure dominates the underground material migration process. Do these processes weaken soil material continuous distribution patterns on the slope surface? If so, does this weaken any soil catena pattern phenomenon?

\subsection{Spatial correspondences between vegetation, and soil, patterns}

Vegetation, and soil, patterns of the dolomitic peak-cluster depressions present a clear spatial correspondence. This is revealed soil catena distribution patterns being compared to vegetation spatial distribution pattern. (Fig. 8). Vegetation patterns can be inferred from soil patterns. The degree of soil development leads to the different structure of vegetation community. This suggests that the different soil types of this soil catena have significantly different vegetation carrying capacities. Herbs were the primary upper-slope entisolic vegetation (Fig. 8). Herb and shrubs were the primary 
mid-slope inceptisolic vegetation. Shrubs were the primary lower-slope semi-alfisolic

446

447

vegetation. Trees were the primary depression alfisolic vegetation.

Water and soil nutrient limitations were the two primary factors leading to vegetation spatial pattern changes (David A. Robinson et al. 2008). This study coupled the soil and vegetation surveys at a complete catena in the dolomite peak-cluster depressions of catchment. The close relationships between soil, and vegetation, distribution patterns were disclosed. However, research results have yet to accurately determine the key environmental factors controlling the spatial relationships between soil and vegetation described above. This is because soil water-retention capacities and soil nutrient capacities have strong synergism as slope decreases. The upper-slope soil was shallow and more gravely. Soil profiles water retention capacities were poor. Soil nutrient stocks were low. Depression soil was relatively deep and less gravelly. It had greater water retention capacities. Soil nutrient stocks were higher (Fig. 8). Soil water retention capacities and soil nutrient stocks show the same trend along the toposequence. A simple factor correlation analysis did not distinguish among the relative contributions of soil water-retention and soil nutrient stocks factor to vegetation distribution patterns. Are dolomite peak-cluster depression vegetation distribution patterns caused by soil moisture retention limitations or soil nutrient limitations, or by the interaction of these two limiting factors, or some other reasons? In-depth research through large-scale investigation and sampling and indoor tests are needed to answer these questions.

\subsection{Quantitative index for evaluating shallow soils' ${ }^{\prime}$ productivity in karst regions}

Soil productivity is the ability of soil to support plant growth. Where climates are similar, highly abundant vegetation and biomass usually indicates high productivity 
(Wang et al. 2015). Non-karst area soil, generally, is deeper and less gravelly. Soil

469

470

471

472

473

474

amount maybe not an important factor limiting its productivity. Therefore, scholars evaluate soil productivity in the deep soil zone by evaluating soil fertility based on the nutrient content of the surface soil (about 0-20 cm), and reflect soil productivity through soil fertility. For example, wu et al. (2018) assessed the productivity status of the black soil zone by taking $0-20 \mathrm{~cm}$ of soil and measuring its nutrient content. For shallow soils like this study, since the total soil amount significantly affects soil productivity, and the shallow soil exhibits significant A-layer nutrient accumulation. Only depend on the Alayer's nutrient content or stock parameters as criterions for assessing soil productivity would significantly overestimate the productivity of the karstic shallow soil.

In this study, it was found that the soil nutrient content was high, but the vegetation in the area was low in number and richness, and low in plant species and diversity. This shows that the nutrient content does not accurately reflect the vegetation characteristics. In this regard, we believe that in this karstic shallow soil zone, the nutrient content may not accurately reflect soil fertility. On the contrary, the nutrient stocks that varied along the toposequence showed the same regularity as the vegetation, and the correlation between them was significant. In addition, the indicators affecting nutrient stocks, such as slope position, soil thickness, sand content, clay content, gravel mass ratio, and fine soil mass ratio, showed the same consistent pattern of variation with vegetation, and the correlation analysis also reflected the significant relationship between the above indirect indicators and vegetation. In summary, comparing nutrient content and nutrient stocks, we propose that nutrient stocks is more applicable to assess soil productivity.

\section{Conclusions}


492

493

494

leads to an undeveloped, fissure-conduit network system. Underground soil creep and fill processes were not obvious for these dolomite hillslopes. Soils concentrated at the surface and show a soil catenary pattern similar to that present in non-karst areas. There was a strong spatial association between soil types and dominant vegetation species. Herbs associated with entisols are on the upper-slope. Herbs and shrubs associated with cambisols are on the middle-slope. Shrubs were associated with semi-luvisols are on the lower-slope. Trees were associated with luvisols are on the depression.

Considering karst hillslope rocky and shallow characteristics, the amount of fine soil was the critical factor controlling vegetation growth. Nutrient stock parameters, and other, the study of more easily measurable parameters, such as topographic position, soil thickness and, gravel mass ratio may more suitable for assessing soil productivity than soil nutrient content parameters in karst regions.

Borehole core characteristics suggest a positive correlation between soil thickness and epikarst thickness. Further research is needed to confirm whether a soil-epikarstvegetation catenary pattern exists in dolomite karst catchments. This study focused on soil and vegetation relationships along a toposequence in this typical dolomite developed catchment. Dolomite rock and limestone are the two predominant types of carbonate rocks in karst regions. Their lithologic and dissolution characteristics differ. These differences lead to apparent different soil-epikarst structural differences between them. Weather soil-epikarst-vegetation catenary is also obvious in peak-cluster depression catchment developed from limestone but this remains to be elucidated. 
514 This study was supported by the National Natural Science Foundation of China 515 (41930866, 42077077, 41671287), the Guangxi Natural Science Foundation of China 516 (2020GXNSFAA297242) and the Central Guided Local Science and Technology 517 Development Fund Project (ZY21195016).

518 
520

521

522

523

524

525

526

527

528

529

530

531

532

533

534

535

536

537

538

539

540

541

542

Applegarth M T, Dahms D E (2001) Soil catenas of calcareous tills, Whiskey Basin, Wyoming, USA. Catena 42(1):17-38. http://dx.doi.org/10.1016/S0341-8162(00)00116-8

Bai, X. Y., S. J. Wang (2011) Relationships between soil loss tolerance and karst rocky desertification. Journal of Natural Resources 26(8):1315-1322. http://dx.doi.org/10.1016/S1671-2927(11)60313-1

Bao SD (2000) Soil agrochemical analysis (3rd edn.). China Agriculture Press, Beijing

Beven, K. J., M. J. Kirkby, J. E. Freer, et al (2021) A history of topmodel. Hydrology and Earth System Sciences 25:527-549. http://dx.doi.org/10.5194/hess-25-527-2021

Boling, A. A., T. P. Tuong, H. Suganda, et al (2008) The effect of toposequence position on soil properties, hydrology, and yield of rainfed lowland rice in Southeast Asia. Field Crops Research 106:22-33. http://dx.doi.org/10.1016/j.fcr.2007.10.013

Brunner A C, Park S J, Ruecker G R, et al (2004) Catenary soil development influencing erosion susceptibility along a hillslope in Uganda. Catena 58(1):1-22. http://dx.doi.org/10.1016/j.catena.2004.02.001

David A. Robinson, Hiruy Abdu, Scott B. Jones, et al (2008) Eco-geophysical imaging of watershed-scale soil patterns links with plant community spatial patterns. Vadose Zone Journal 7(4):1132-1138. http://dx.doi.org/10.2136/vzj2008.0101

Deressa A, M. Yli-Halla, M. Mohamed, et al (2018) Soil classification of humid western ethiopia: a transect study along a toposequence in Didessa watershed. Catena 163: 184-195. http://dx.doi.org/10.1016/j.catena.2017.12.020.

D Ford, Williams P W (2015) Karst Hydrogeology and Geomorphology. Wiley.

Ding, Y. L., Y. P. Nie, H. S. Chen, et al (2021) Water uptake depth is coordinated with leaf water potential, water-use efficiency and drought vulnerability in karst vegetation. New Phytologist 
544 Fei W, Qin F, Wu D, et al (2015) Comparative study on the calculation method of soil organic matter

545 and organic carbon. Journal of Agriculture 5(03):54-58.

Feng, T., H. S. Chen, V. O. Polyakov, et al (2016) Soil erosion rates in two karst peak-cluster depression basins of northwest Guangxi, China: Comparison of the RUSLE model with (CS)C-137 measurements.

$$
\text { http://dx.doi.org/10.1016/j.geomorph.2015.10.013 }
$$

Gilfillan S, Lollar B S, Holland G, et al (2009) Solubility trapping in formation water as dominant $\mathrm{CO}_{2}$ sink in natural gas fields. Nature 458(7238):614-618. http://dx.doi.org/10.1038/nature07852

Hartmann, A., T. Gleeson, Y. Wada, et al (2017) Enhanced groundwater recharge rates and altered recharge sensitivity to climate variability through subsurface heterogeneity. Proceedings of the National Academy of Sciences of the United States of America 114:2842-2847. http://dx.doi.org/10.1073/pnas.1614941114

Hong-Liang Wu, Wang S C, Sheng-Chang H, et al (2018) Evolutionary characteristics of fertility and productivity of typical black soil in recent 30 years. Journal of Plant Nutrition and Fertilizers 24(6): 1456-1464. http://dx.doi.org/10.11674/zwyf.18238

Hu K, Chen H, Nie Y, et al (2015) Seasonal recharge and mean residence times of soil and epikarst water in a small karst catchment of southwest China. Scientific Reports 5:10215. http://dx.doi.org/10.1038/srep10215

Jiang Z (1999) Dynamics features of the epikarst zone and their significance in environments and resources. Acta Geosicientia Sinica 20(3):302-308. http://dx.doi.org/10.3321/j.issn:10063021.1999 .03 .014

Jiang, Z., Y. Lian, and X. Qin (2014) Rocky desertification in Southwest China: Impacts, causes, 
568 http://dx.doi.org/10.1016/j.earscirev.2014.01.005

Li, A., and X. Duan (2014) Productivity assessment for black soil region in northeastern china using black soil thickness a case study of hebei watershed. Bulletin of Soil and Water Conservation 34:154-159. http://dx.doi.org/10.13961/j.cnki.stbctb.2014.01.044

Liu H, Jiang Z, Dai J, et al (2019) Rock crevices determine woody and herbaceous plant cover in the karst critical zone. Science China Earth Sciences 62: 1756-1763, https://doi.org/10.1007/s11430-018-9328-3

Lozano-García, B. and Parras-Alcántara, L (2014) Variation in soil organic carbon and nitrogen stocks along a toposequence in a traditional mediterranean olive grove. land degrad. develop 25: 297-304. https://doi.org/10.1002/ldr.2284

Nie Y (1994) Karst development characteristics under the lithologic control of carbonate rocks-a case study in south-central Guizhou. Carsologica sinica (01):31-36. (in Chinese)

Nie Y P, Chen H S, Wang K L, et al (2011) Seasonal water use patterns of woody species growing on the continuous dolostone outcrops and nearby thin soils in subtropical China. Plant \& Soil 341(1-2):399-412. https://doi.org/10.1007/s11104-010-0653-2

Podwojewski P, Poulenard J, Nguyet M L, et al (2011) Climate and vegetation determine soil organic matter status in an alpine inner-tropical soil catena in the Fan Si Pan Mountain, Vietnam. Catena 87(2):226-239. http://dx.doi.org/10.1016/j.catena.2011.06.002

Schlichting, E (1970) Bodensystematik und Bodensoziologie. Journal of Plant Nutrition and Soil Science $=$ Zeitschrift fuer Pflanzenernaehrung und Bodenkunde 127:1-9. http://dx.doi.org/10.1002/jpln.19701270102

Sommer, M., and E. Schlichting (1997) Archetypes of catenas in respect to matter - A concept for structuring and grouping catenas. Geoderma 76:1-33. http://dx.doi.org/10.1016/S0016- 
592

593

594

595

596

597

598

599

600

601

602

603

604

605

606

607

608

609

Tsai, CC, Chen, et al (2010) Pedogenic development of volcanic ash soils along a climosequence in Northern

Taiwan.

Geoderma

156(1-2):48-59.

$$
\text { http://dx.doi.org/10.1016/j.geoderma.2010.01.007 }
$$

U.S. Department of Agriculture. Soil Survey Laboratory Information Manual - Soil Survey Investigations Report No. 45 (Version 2.0).

Wang J Y, Yan X Y, Gong W (2015) Effect of Long-Term Fertilization on Soil Productivity on the North China Plain. Pedosphere 25(3):450-458. http://dx.doi.org/10.1016/S10020160(15)30012-6

Wang X, Cai C, Li H, et al (2017) Influence of rock fragments on bulk density and pore characteristics of purple soil in Three-gorge Reservoir area. Acta Pedologica Sinica 54(02):379-386. http://dx.doi.org/10.11766/trxb201601050569

Williams P W (1983) The role of the subcutaneous zone in karst hydrology. Journal of Hydrology 61(1-3):45-67. http://dx.doi.org/10.1016/0022-1694(83)90234-2

Worthington S, Davies G J, Alexander E C (2016) Enhancement of bedrock permeability by $\begin{array}{lll}\text { weathering. } & \text { Earth-Science } \quad \text { Reviews }\end{array}$ http://dx.doi.org/10.1016/j.earscirev.2016.07.002

Wrb I (2006) World Reference Base for Soil Resources. A Framework for International Classification, Correlation and Communication. World Soil Resources Reports. 
611 Table 1 Site characteristics, soil hydrological conditions, and soil-rock profile morphology at 612 different topographic positions

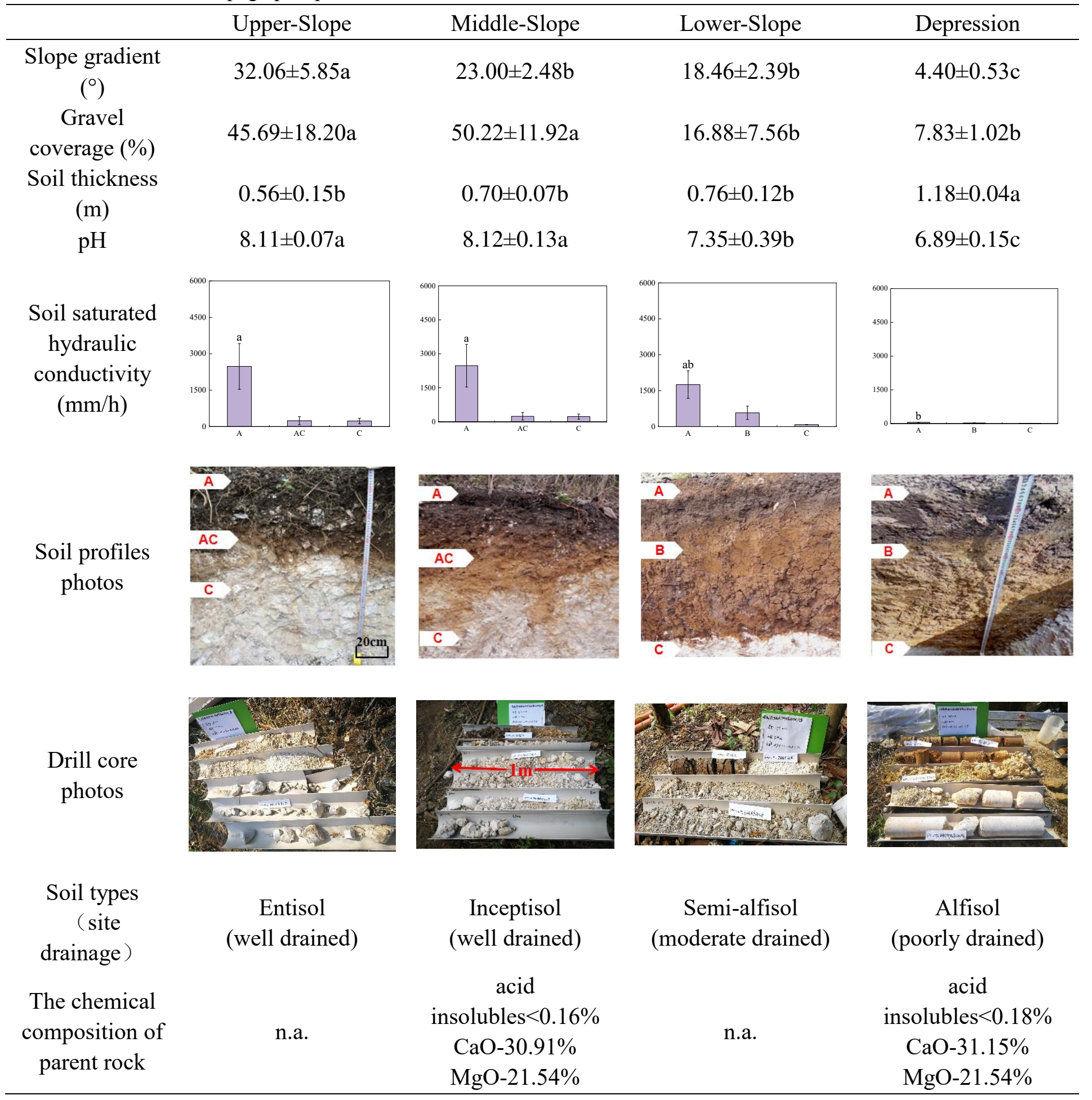

613 Note: Lowercase ( $a, b)$ represent the Anova results in same parameters $(\mathrm{p}<0.05)$.

614 n.a.: not analysed. 
Table 2 Physical properties of soil genetic horizons for different topographic positions

\begin{tabular}{|c|c|c|c|c|c|c|c|c|c|c|c|}
\hline $\begin{array}{l}\text { Topographic } \\
\text { position } \\
\text { (soil } \\
\text { type) }\end{array}$ & $\begin{array}{l}\text { pedon } \\
\text { scale }\end{array}$ & $\begin{array}{l}\text { Genetic } \\
\text { horizon }\end{array}$ & $\begin{array}{c}\text { Soil } \\
\text { thicknes } \\
\mathrm{s}(\mathrm{cm})\end{array}$ & $\begin{array}{c}\text { BD } \\
(\mathrm{g} / \mathrm{cm} \\
3)\end{array}$ & $\begin{array}{c}\delta_{f} \\
\left(\mathrm{~g} / \mathrm{cm}^{3}\right)\end{array}$ & $\begin{array}{c}\text { Sand } \\
(\%)\end{array}$ & $\begin{array}{l}\text { Slit } \\
(\%)\end{array}$ & $\begin{array}{l}\text { Clay } \\
(\%)\end{array}$ & $\begin{array}{c}\mathrm{m}_{1} \\
\left(\mathrm{~kg} / \mathrm{m}^{2}\right)\end{array}$ & $\begin{array}{c}\mathrm{m}_{2} \\
\left(\mathrm{~kg} / \mathrm{m}^{2}\right)\end{array}$ & $\begin{array}{c}\mathrm{m}_{\mathrm{t}} \\
\left(\mathrm{kg} / \mathrm{m}^{2}\right)\end{array}$ \\
\hline \multirow{8}{*}{$\begin{array}{c}\text { Upper } \\
\text {-Slope } \\
\text { (Entisol) }\end{array}$} & \multirow{2}{*}{ U1 } & A & $0-25$ & 1.18 & 0.78 & 52.66 & 22.53 & 24.81 & 340.38 & 73.65 & 414.03 \\
\hline & & $\mathrm{C}$ & $25-59$ & 1.46 & 1.21 & 85.13 & 7.99 & 6.87 & 482.67 & 155.24 & 637.90 \\
\hline & \multirow{3}{*}{ U2 } & A & $0-17$ & 1.34 & 1.22 & 59.74 & 17.39 & 22.87 & 193.19 & 98.28 & 291.47 \\
\hline & & $\mathrm{AC}$ & $17-42$ & 1.51 & 1.24 & 76.22 & 7.95 & 15.83 & 501.10 & 70.44 & 571.54 \\
\hline & & $\mathrm{C}$ & $42-69$ & 1.80 & 0.62 & 98.17 & 1.00 & 0.83 & 445.47 & 52.55 & 498.03 \\
\hline & \multirow{3}{*}{ U3 } & A & $0-22$ & 1.22 & 0.45 & 59.74 & 16.39 & 23.87 & 272.01 & 45.80 & 317.81 \\
\hline & & $\mathrm{AC}$ & $22-40$ & 1.83 & 0.86 & 96.22 & 3.05 & 0.73 & 335.10 & 34.38 & 369.48 \\
\hline & & $\mathrm{C}$ & $>40$ & n.a. & n.a. & n.a. & n.a. & n.a. & n.a. & n.a. & n.a. \\
\hline \multirow{12}{*}{$\begin{array}{l}\text { Middle } \\
\text {-Slope } \\
\text { (Inceptisol } \\
\quad \text { ) }\end{array}$} & \multirow{3}{*}{ M1 } & A & $0-22$ & 1.25 & 0.66 & 61.62 & 22.55 & 15.83 & 290.82 & 62.21 & 353.03 \\
\hline & & $\mathrm{AC}$ & $22-48$ & 1.79 & 1.34 & 60.29 & 20.89 & 18.82 & 340.11 & 125.36 & 465.47 \\
\hline & & $\mathrm{C}$ & $48-71$ & 1.43 & 0.34 & 92.72 & 7.00 & 0.28 & 299.11 & 34.89 & 334.00 \\
\hline & \multirow{3}{*}{ M2 } & A & $0-25$ & 1.11 & 0.58 & 56.19 & 19.99 & 23.82 & 173.96 & 103.95 & 277.91 \\
\hline & & $\mathrm{AC}$ & $25-51$ & 1.36 & 0.57 & 61.73 & 18.40 & 19.88 & 267.90 & 84.65 & 352.55 \\
\hline & & $\mathrm{C}$ & $51-72$ & 1.56 & 0.64 & 91.21 & 7.93 & 0.87 & 255.36 & 71.07 & 326.44 \\
\hline & \multirow{3}{*}{ M3 } & A & $0-18$ & 1.29 & 0.65 & 60.73 & 19.40 & 19.88 & 151.93 & 75.59 & 227.52 \\
\hline & & $\mathrm{AC}$ & $18-53$ & 1.62 & 0.49 & 86.25 & 4.94 & 8.81 & 482.63 & 84.01 & 566.64 \\
\hline & & $\mathrm{C}$ & $53-75$ & 1.75 & 0.19 & 97.22 & 1.95 & 0.83 & 257.06 & 20.25 & 277.31 \\
\hline & \multirow{3}{*}{ M4 } & A & $0-40$ & 1.14 & 0.17 & 63.72 & 17.40 & 18.88 & 416.34 & 38.82 & 455.16 \\
\hline & & $\mathrm{AC}$ & $40-60$ & 1.13 & 0.45 & 81.12 & 9.00 & 9.88 & 206.00 & 49.54 & 255.54 \\
\hline & & $\mathrm{C}$ & $>60$ & n.a. & n.a. & n.a. & n.a. & n.a. & n.a. & n.a. & n.a. \\
\hline \multirow{12}{*}{$\begin{array}{l}\text { Lower } \\
\text {-Slope } \\
\text { (Semi- } \\
\text { alfisol） }\end{array}$} & \multirow{3}{*}{ L1 } & A & $0-20$ & 1.05 & 1.04 & 32.31 & 25.88 & 41.80 & 1.17 & 200.52 & 201.69 \\
\hline & & B & $20-45$ & 1.26 & 1.20 & 30.31 & 23.89 & 45.80 & 0.33 & 288.60 & 288.93 \\
\hline & & $\mathrm{C}$ & $45-80$ & 1.46 & 1.45 & 57.64 & 32.54 & 9.83 & 0.01 & 505.08 & 505.08 \\
\hline & \multirow{3}{*}{ L2 } & A & $0-25$ & 1.04 & 1.03 & 32.23 & 29.94 & 37.82 & 2.98 & 254.16 & 257.14 \\
\hline & & B & $25-61$ & 1.19 & 1.18 & 22.28 & 14.04 & 63.68 & 0.00 & 424.21 & 424.21 \\
\hline & & $\mathrm{C}$ & $>61$ & n.a. & n.a. & n.a. & n.a. & n.a. & n.a. & n.a. & n.a. \\
\hline & \multirow{3}{*}{ L3 } & A & $0-15$ & 1.09 & 1.08 & 44.31 & 20.02 & 35.67 & 0.14 & 162.03 & 162.16 \\
\hline & & B & $15-90$ & 1.21 & 1.20 & 18.27 & 13.04 & 68.69 & 0.33 & 901.66 & 901.99 \\
\hline & & $\mathrm{C}$ & $>90$ & n.a. & n.a. & n.a. & n.a. & n.a. & n.a. & n.a. & n.a. \\
\hline & \multirow{3}{*}{$\mathrm{L} 4$} & A & $0-15$ & 1.05 & 1.05 & 44.39 & 17.99 & 37.62 & 0.13 & 157.14 & 157.27 \\
\hline & & B & $15-71$ & 1.17 & 1.17 & 35.73 & 8.4 & 55.87 & 0.00 & 654.11 & 654.11 \\
\hline & & $\mathrm{C}$ & $>71$ & n.a. & n.a. & n.a. & n.a. & n.a. & n.a. & n.a. & n.a. \\
\hline \multirow{9}{*}{$\begin{array}{c}\text { Depression } \\
\text { (Alfisol) }\end{array}$} & \multirow{3}{*}{ D1 } & A & $0-20$ & 1.25 & 1.25 & 27.65 & 32.32 & 40.03 & 0.47 & 249.53 & 250.00 \\
\hline & & B & $20-100$ & 1.21 & 1.21 & 20.53 & 30.84 & 48.63 & 0.30 & 965.87 & 966.17 \\
\hline & & $\mathrm{C}$ & $100-120$ & 1.13 & 1.33 & 19.37 & 30.54 & 50.09 & 0.00 & 265.83 & 265.83 \\
\hline & \multirow{3}{*}{ D2 } & A & $0-25$ & 1.28 & 1.28 & 26.87 & 32.01 & 41.12 & 1.15 & 317.80 & 318.95 \\
\hline & & B & $25-110$ & 1.30 & 1.30 & 17.77 & 36.73 & 45.5 & 0.14 & 1100.54 & 1100.68 \\
\hline & & $\mathrm{C}$ & $110-120$ & 1.34 & 1.44 & 15.34 & 38.24 & 46.42 & 0.00 & 143.92 & 143.92 \\
\hline & \multirow{3}{*}{ D3 } & A & $0-28$ & 1.32 & 1.32 & 21.03 & 31.62 & 47.35 & 0.55 & 368.95 & 369.49 \\
\hline & & B & $28-97$ & 1.41 & 1.41 & 18.41 & 34.28 & 47.31 & 0.28 & 972.30 & 972.58 \\
\hline & & $\mathrm{C}$ & $97-113$ & 1.38 & 1.38 & 17.38 & 34.43 & 48.19 & 220.73 & 0.01 & 0.05 \\
\hline
\end{tabular}




\section{7 soil mass per unit area. $\mathrm{m}_{\mathrm{t}}$ is soil mass per unit area.}

n.a.: not analysed. 
619 Table 4 Vegetation characteristics for different topographic positions

\begin{tabular}{ccccc}
\hline $\begin{array}{c}\text { Topographic } \\
\text { positions }\end{array}$ & Vegetation Types & $\begin{array}{c}\text { Number of plant } \\
\text { species }\end{array}$ & Plants number & Percentage $(\%)$ \\
\hline \multirow{2}{*}{ Upper-Slope } & trees & 3 & 63 & 18.10 \\
& shrubs & 10 & 126 & 36.21 \\
& herbs & 3 & 159 & 45.69 \\
\hline \multirow{2}{*}{ Middle-Slope } & trees & 1 & 41 & 15.53 \\
& shrubs & 7 & 154 & 58.33 \\
& herbs & 5 & 69 & 26.14 \\
\hline \multirow{2}{*}{ Lower-Slope } & trees & 9 & 54 & 13.95 \\
& shrubs & 10 & 241 & 62.27 \\
& herbs & 6 & 92 & 23.77 \\
\hline \multirow{2}{*}{ Depression } & trees & 4 & 121 & 42.01 \\
& shrubs & 2 & 7 & 2.43 \\
& herbs & 5 & 160 & 55.56 \\
\hline
\end{tabular}

620 The statistics of the above values were on a $400 \mathrm{~m}^{2}$ sample. Percentage is the ratio different

621 vegetation types to the total plant number. 
623 Fig. 1 Location and geohydrologic background of the study area

624 Fig. 2 Pedon scale mass ratio and volume ratio of gravel and fine soil for different topographic 625 positions

626 Fig. 3 Pedon scale grain size distribution of the fine soil fractions for different topographic

627 positions

628 Fig. 4 Pedon scale average nutrient content and nutrient stocks for different topographic positions

629 Fig. 5 The ratio of A-horizon's nutrient stock to pedon scale nutrient stocks

630 Fig. 6 The ratio of A-horizon's fine soil volume to pedon scale fine soil volume

631 Fig. 7 The correlation between topographic factors, soil properties, and vegetation factors

632 Fig. 8 A schematic representation of soil catena and its effects on vegetation spatial pattern along the toposequence in the peak-cluster depression catchment developed from dolomite rocks 


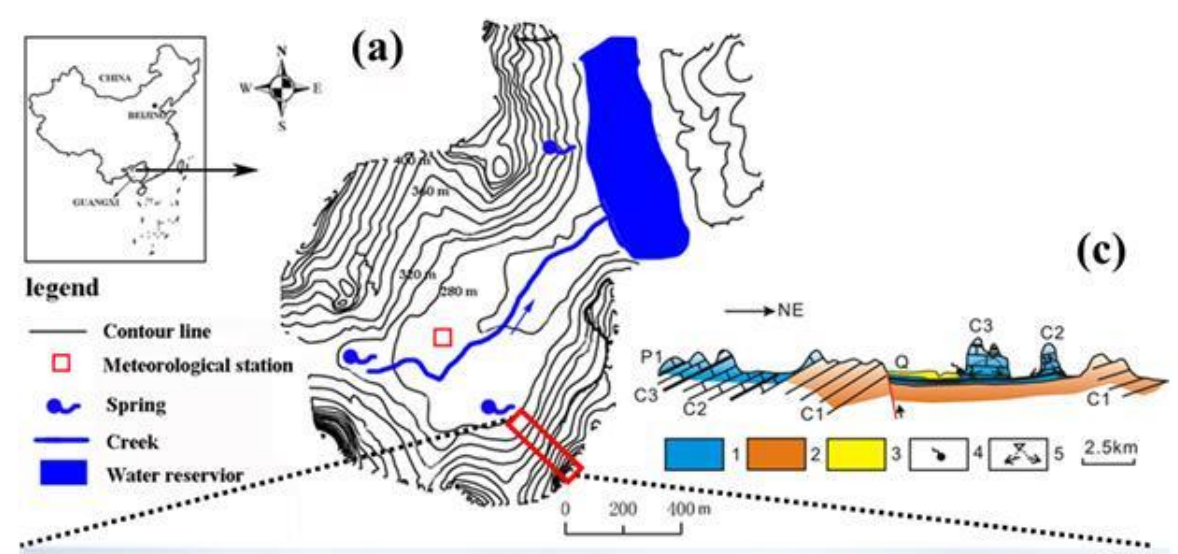

(b)

636 (a) Mulian catchment in Huanjiang county, Guangxi, China, topographical map; (b) the peak-cluster

637 depression karst landscape the soil and vegetation locations along the toposequence; and, (c)

638 geohydrologic background of the study catchment. 1, 2, 3, 4, and 5 indicate the karst aquifer; the

639 sandstone aquifer, a relatively impermeable layer; the porous quaternary aquifer; the spring and

640 ground water flow paths, respectively. P1 is is early Permian. Q is Quaternary. C1, C2, and C3

641 indicate the early, middle and late Carboniferous, respectively.

642 Fig. 1 Location and geohydrologic background of the study area 

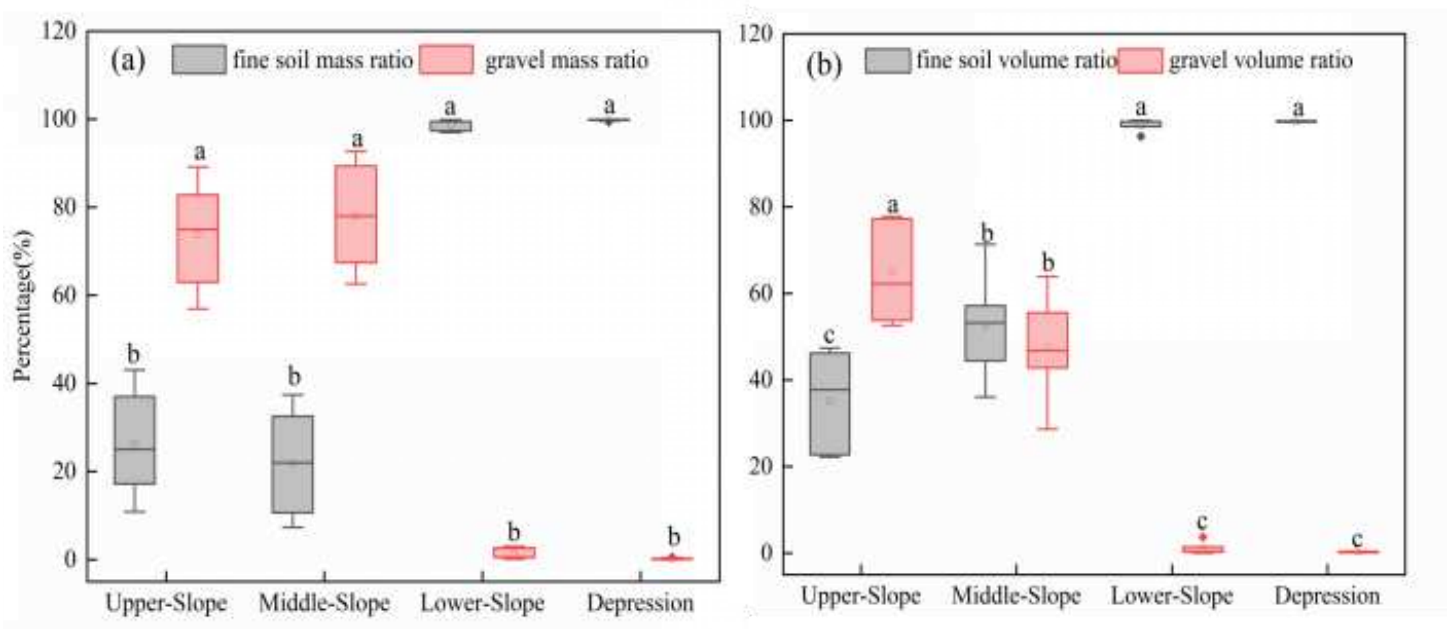

645 Note: The lowercase letters indicate significant differences between slope positions $(\mathrm{P}<0.05)$.

646 Fig. 2 Pedon scale mass ratio and volume ratio of gravel and fine soil for different topographic

647 positions

648 


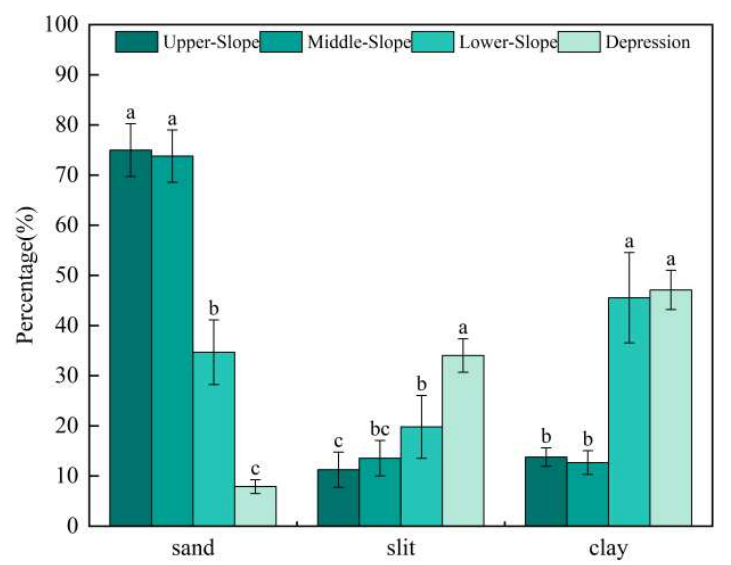

651 Fig. 3 Pedon scale grain size distribution of the fine soil fractions for different topographic 

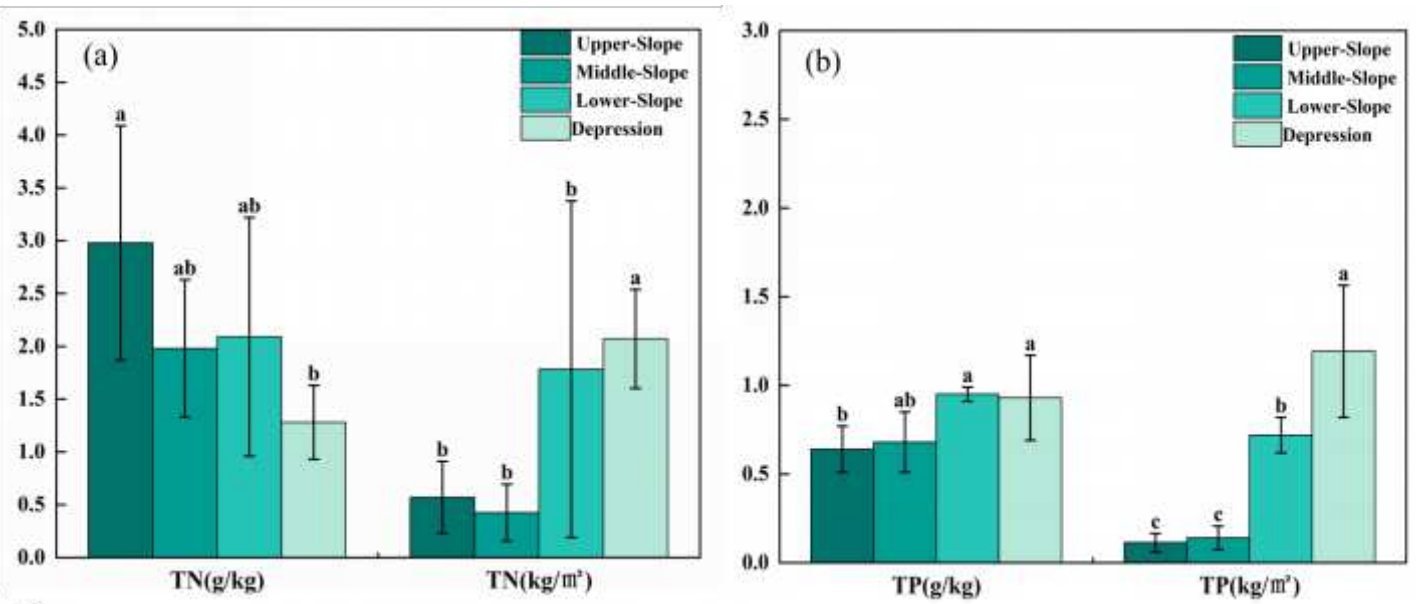

653
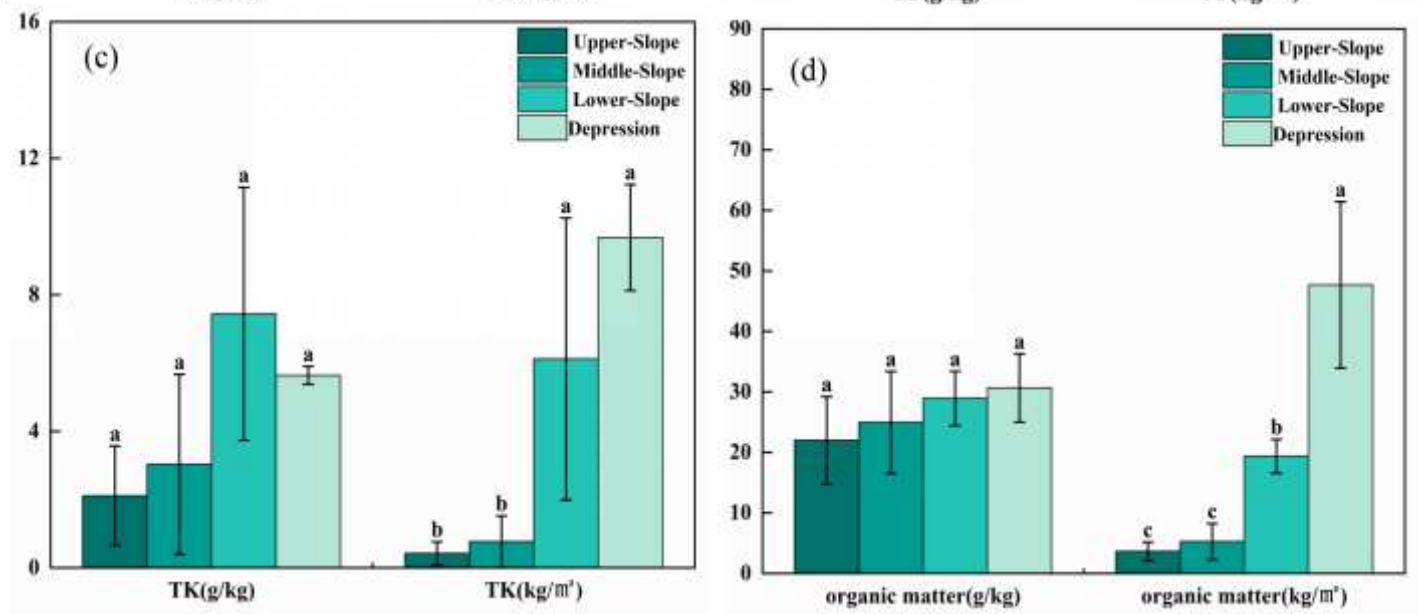

654 In Figures a, b, c, and d, the left is part represents the nutrient content and the right part represents the nutrient stocks.

Fig. 4 Pedon scale average nutrient content and nutrient stocks for different topographic positions 


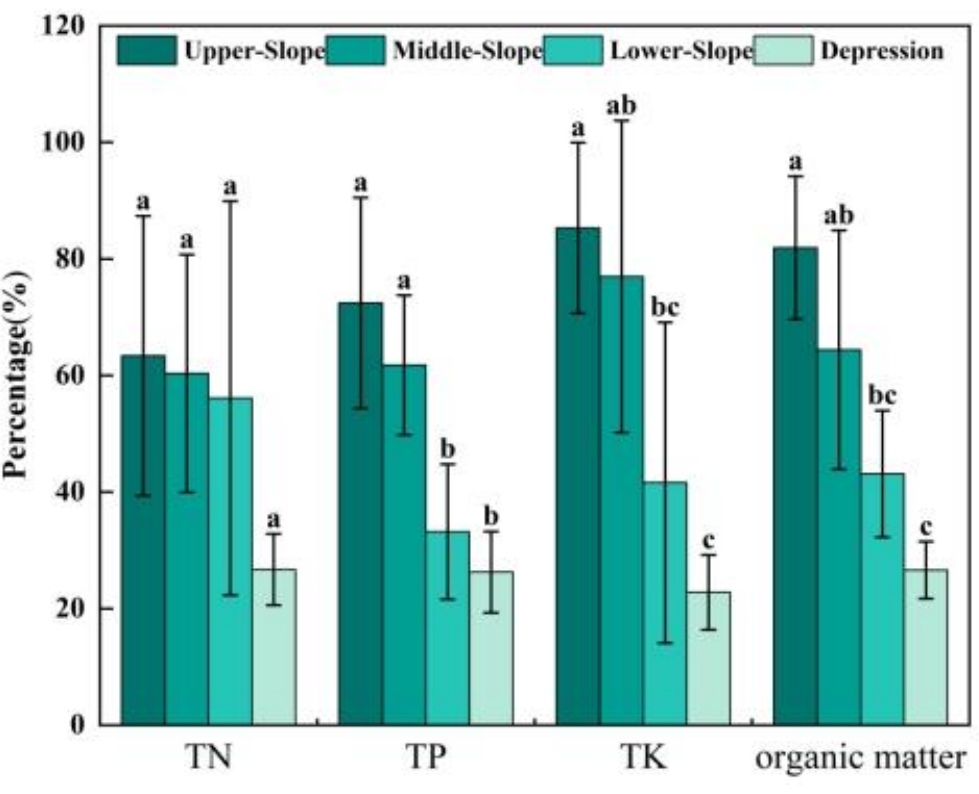

659 Fig. 5 The ratio of A-horizon's nutrient stock to pedon scale nutrient stock 


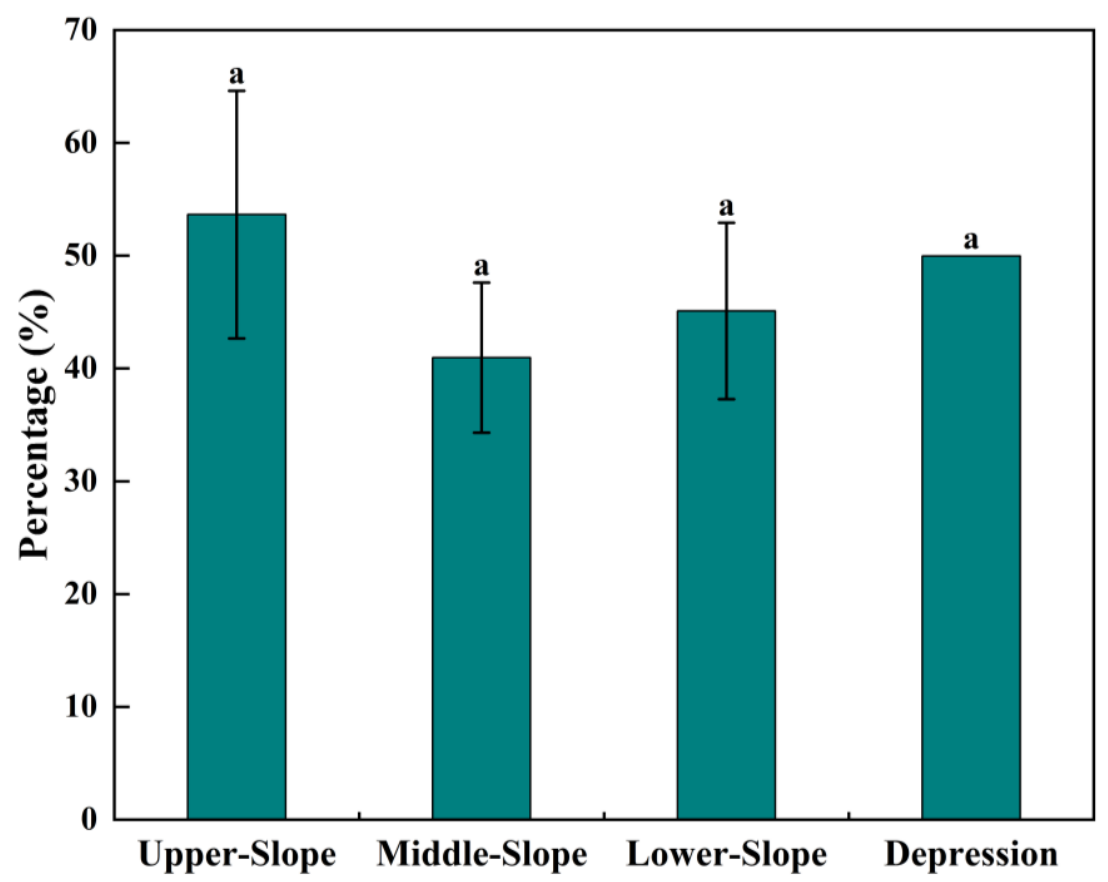

662 Fig. 6 The ratio of A-horizon's fine soil volume to pedon scale fine soil volume 
663

664

665

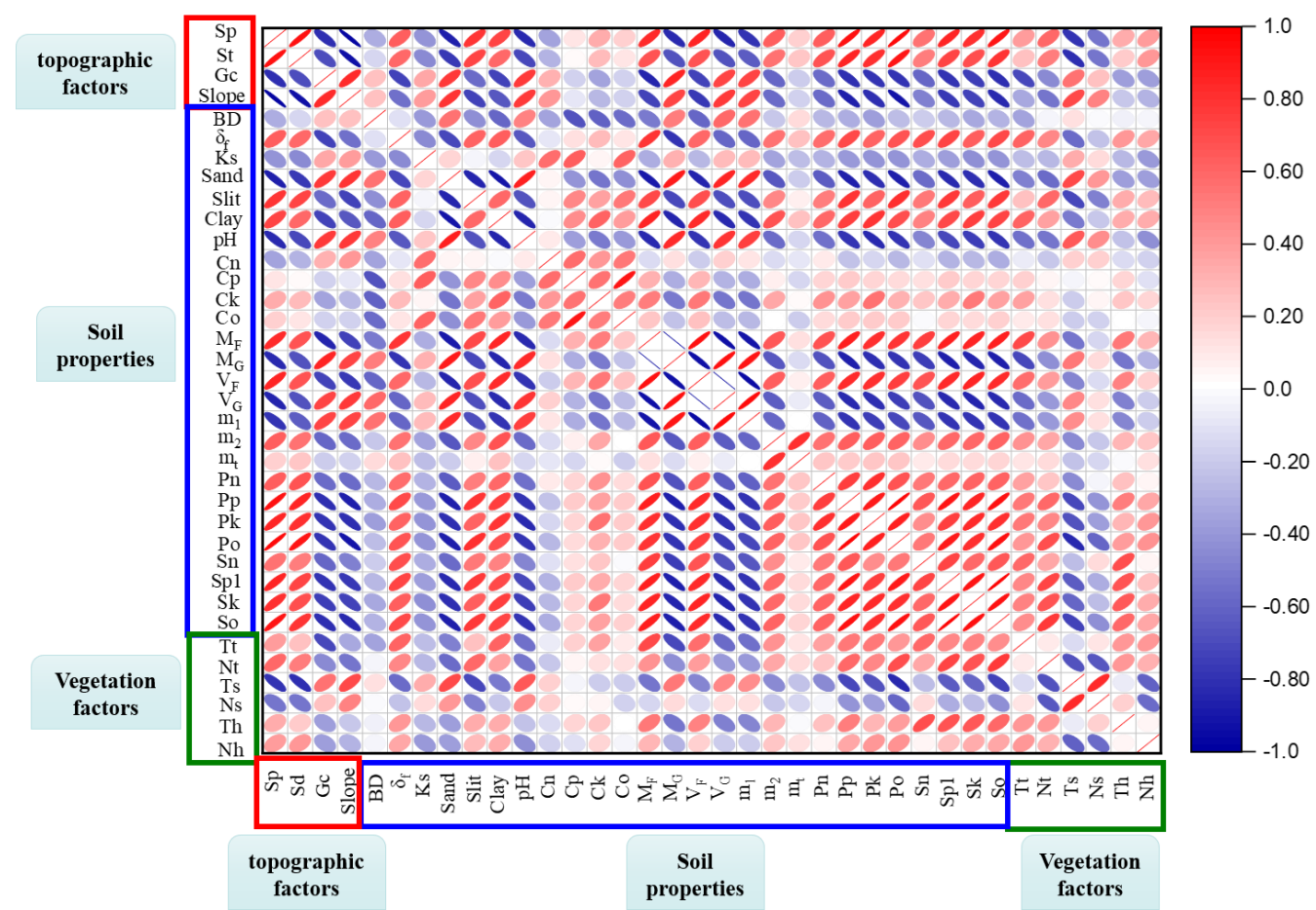

Note: $\mathrm{Sp}$ is slope position. Sd is Soil depth. Gc is gravel coverage. BD is bulk density. $\delta_{f}$ is fine soil $\mathrm{BD}$. $\mathrm{Cn}$ is nitrogen content. $\mathrm{Cp}$ is phosphorus content. $\mathrm{Ck}$ is potassium content. $\mathrm{Co}$ is organic matter content. $\mathrm{M}_{\mathrm{F}}$ is fine soil content. $\mathrm{M}_{\mathrm{G}}$ is gravel content. $\mathrm{V}_{\mathrm{F}}$ is fine soil volume ratio. $\mathrm{V}_{\mathrm{G}}$ is gravel volume. $m_{1}$ is gravel per unit area mass. $m_{2}$ is fine soil per unit area mass. $m_{t}$ is the total mass of soil per unit area, Pn is the pedon total nitrogen stocks, Pp is the pedon total phosphorus stocks, $\mathrm{Pk}$ is the pedon total potassium stocks, Po is the pedon organic matter stocks, $\mathrm{Sn}$ is the total nitrogen stocks of A layer, $\mathrm{Sp} 1$ is the total phosphorus stocks of A layer, Sk is the total potassium stocks of A layer, So is the stocks of organic matter in A layer, $\mathrm{Tt}$ is tree types, $\mathrm{Nt}$ is the number of trees, Ts is the type of shrub, Ns is the number of shrub, Th is the type of herb, Nh is the amount of herb.

Fig. 7 The correlation between topographic factors, soil properties, and vegetation factor 


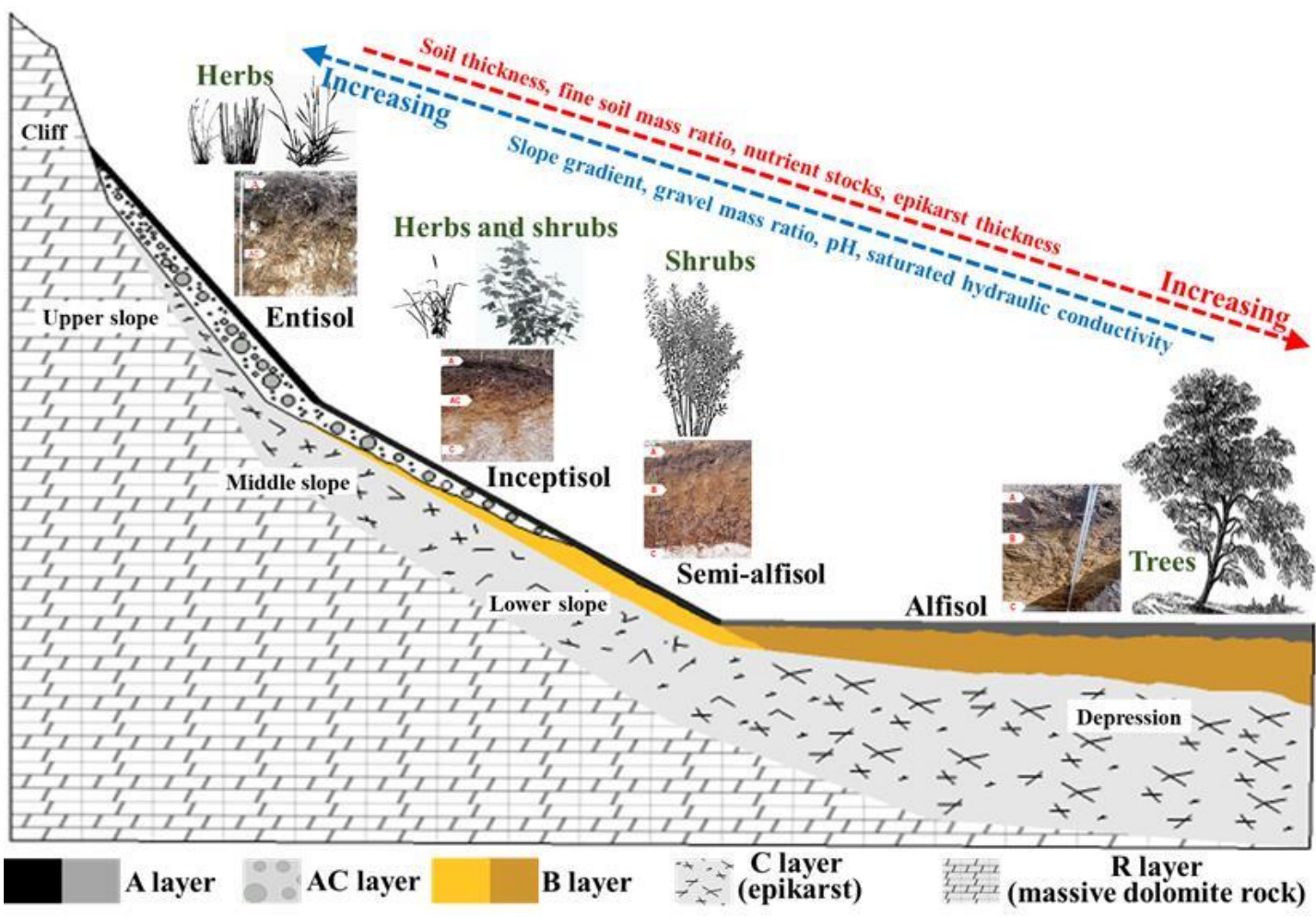

677 Fig. 8 A schematic representation of soil catena and its effects on vegetation spatial pattern along

678 the toposequence in the peak-cluster depression catchment developed from dolomite rocks 


\section{Supplementary Files}

This is a list of supplementary files associated with this preprint. Click to download.

- supplementfile.docx 